\title{
Achieving the Goal of the London Summit on Family Planning By Adhering to Voluntary, Rights-Based Family Planning: What Can We Learn from Past Experiences with Coercion?
}

By Karen Hardee,

Shannon Harris,

Mariela Rodriguez,

Jan Kumar, Lynn

Bakamjian, Karen

Newman and

Win Brown

At the time the article was written, Karen

Hardee was senior

fellow, and Mariela

Rodriguez was re-

search associate, both

at Futures Group,

Washington, DC.

Jan Kumar is senior

technical advisor,

EngenderHealth, New

York. Shannon Har-

ris, Lynn Bakamjian

and Karen Newman

are independent con-

sultants, in Seattle,

WA, USA, New York

and London, respec-

tively. Win Brown is

senior program officer,

Bill \& Melinda Gates

Foundation, Seattle.
The 2012 London Summit on Family Planning refocused attention on family planning, garnering much-needed support for the goal of reenergizing and expanding programs in 69 low- and medium-income countries "to enable 120 million more women...to use contraceptives by 2020." Although the response to the summit's initiative (referred to as "FP2020") was generally positive, reproductive health and rights advocates expressed concern that the focus on a numeric goal was a retreat from the 1994 consensus of the International Conference on Population and Development (ICPD), which promoted rights and repudiated targets. ${ }^{2-5}$ Following the London Summit, some advocates questioned how the ambitious goal of the initiative might be achieved, and at least one commenter raised the specter of coercion-without the proper safeguards, would the rights of women, ostensibly the center of the initiative, be protected? ${ }^{2}$

The international family planning movement was built on the foundation of the right of individuals and couples to decide freely and responsibly the number and spacing of their children and to obtain the information and services to do so, although the goal of several early family planning programs was to slow population growth. ${ }^{6}$ The vast majority of family planning has been provided through programs that adhere to principles of voluntarism, but instances and allegations of coercion over the last several decades have dogged international family planning, and have evoked strong reactions. ${ }^{7-15}$ Indeed, the family planning field has been wrestling with the issue of coercion for decades. ${ }^{16}$

The purpose of this article is to answer the following questions: What constitutes coercion in family planning policy and program management and how do we use lessons of the past to prevent future instances of coercion? We contend that defining coercion and examining when it has occurred (or has been alleged to have occurred) in family planning programs will aid in the development of safeguards to reduce the incidence of coercion, will help protect or redeem programs that are falsely accused of coercion, and will help ensure that programming supported by the FP2020 initiative provides voluntary family planning services that respect, protect and fulfill human rights.

\section{METHODS}

This article is based on a review of the literature on alleged and documented cases of coercion in family planning programs, augmented by the authors' direct experience with and research on family planning programs, demography, quality of care and human rights since the 1970s. The literature for this article is supplemented by a wider review of literature conducted on voluntary, human rights-based family planning by Rodriguez et al. ${ }^{17}$ While Rodriguez et al.'s literature review focused on the years 1995-2012, this article includes literature from family planning programming dating back to the 1960 s, because some instances and allegations of coercive practices included here occurred at that time.

\section{What Constitutes Coercion?}

To inform this article, we looked for existing definitions and descriptions of coercion in family planning. ${ }^{18,19}$ There is no commonly held definition, although instances of coercion are linked to violations of human rights and there is broad consensus that coercion is morally wrong and should be avoided by family planning programs. ${ }^{18,20-22}$ To develop a definition of coercion, we found it instructive to review the three broad categories of reproductive rights described by Erdman and Cook-the right to reproductive self-determination; rights to sexual and reproductive health services, information and education; and rights to equality and nondiscrimination. ${ }^{23}$

Defining coercion or coercive actions too broadly could incriminate all family planning programs, becoming a catchall term applied to poorly implemented programs that neglect or are unable to reach quality of care standards. We contend that for the term coercion to be useful for advocacy and accountability purposes, it should not be conflated with broader issues of quality of care or equity, which deserve equal, if not more, attention and are also linked with human rights violations. Considering these factors, we propose the following definition: Coercion in family planning consists of actions or factors that compromise individual autonomy, agency or liberty in relation to contraceptive use or reproductive decision making through force, violence, intimidation or manipulation.

Under this definition, coercion is a violation of the right to reproductive self-determination, including the right to bodily integrity (autonomy over one's own body). It is important to note that coercion is not the only way in which the right to reproductive self-determination can be violated; denying services to individuals also violates their rights. To illustrate actions and factors that may fit under this definition, this article focuses on policies and program management that explicitly foster practices that compromise, or have the potential to compromise, autonomy, agency or liberty when implemented. 


\section{Violations and Red Flags Related to Coercion}

There is a spectrum of coercive practices that can arise from policies and program management. We have identified five program practices that are either violations (coercion is clearly occurring or is very likely to occur) or red flags (the potential for coercion exists) in family planning or population policies: enforcement of policies that limit the numbers of births allowed to individuals or couples; enforcement of mandatory contraceptive use policies and family planning procedures undertaken without a client's knowledge or against her or his will; use of social pressure to enforce family planning adoption; family planning use as a target or performance indicator; and provision of financial or other incentives or disincentives.

The first two elements are certainly coercive and are thus considered violations. When enforced, policies that limit the number of births allowed to individuals clearly violate human rights, as do enforced mandatory contraceptive use policies. ${ }^{24}$ Using social pressure, using family planning use as a performance indicator, and providing incentives or disincentives all have the potential for creating coercive pressures in family planning programs. However, more benign versions of these actions (i.e., working with local leaders to change family planning norms and acceptability, setting goals as part of program management, reimbursing clients for travel and lost wages to allow increased access, etc.) are program activities intended to expand access to family planning and improve management of programs. These well-intentioned actions can be taken to an extreme or be misinterpreted. They are considered red flags because their use needs to be monitored to ensure that they do not progress to harmful practices that compromise the capacity of family planning acceptors to make a full, free and informed choice.

This article focuses on policy and program management actions related to implementation of family planning programs; it does not cover other types of coercion, such as involuntary childbearing or forced sterilization caused by stigma and discrimination or pronatalist policies, though these are critically important from a human rights perspective. ${ }^{11,15,19,25}$ Also, the article does not address involuntary pregnancy or childbirth that can result from lack of access to or stockouts of contraceptives or limited method choice, although these conditions affect millions of women and are a critical focus of the FP2020 initiative. Furthermore, the article does not address abortion services, the lack of which many contend results in involuntary childbearing. ${ }^{11}$

\section{RESULTS}

We have organized the findings according to the five program elements identified above as violations or red flags and provide examples of where these practices have been used. A few countries with a long history of family planning are discussed under more than one element. As seen in these examples, in the cases of strong social pressure, targets and incentives, there are debates about whether these practices actually constituted coercion. And finally, we highlight situations where there is concern about the potential for coercion in more recently implemented family planning programs.

\section{Policies to Limit Births}

Although countries have legitimate reasons to consider and plan for population dynamics, policies that limit childbearing go against the 1968 International Conference on Human Rights, which gave individuals and couples the right to decide on the number and spacing of their children. ${ }^{6}$ Family planning programs have a long history of promoting a small family norm; many family planning posters extol the advantages of a small family over a large family.

However, policies that explicitly limit the number of children individuals and couples may have are coercive. The most well-known of these child-limitation policies is China's one-child policy, ${ }^{13}$ which is finally showing signs of loosening after more than 30 years.

Demographic concerns also led Vietnam to implement a one-or-two-child policy in 1988 that required 3-5 years between births and had other specifications, such as minimum age at childbearing. ${ }^{26}$ Following the 1994 ICPD, Vietnam shifted to a comprehensive reproductive health approach and in 2003, the government issued a population ordinance that supported the right of couples to freely choose the number of children they wanted. ${ }^{27,28}$ After a "population surge" occurred following the policy shift in 2003, the political bureau of the Vietnamese Communist Party responded with a resolution strongly supporting a two-child limit for Vietnamese families, ${ }^{27}$ although there are few indications that people are forced to comply with the policy. The Vietnamese family planning program promotes voluntary, quality services. ${ }^{29}$ However, because of the twochild resolution, there is potential for coercive practices.

The most recent example of imposition of a childlimitation policy occurred in 2013 in Myanmar and may be the first modern child-limitation policy to target a religious group. ${ }^{30}$ Recent reports have revealed that Myanmar is enforcing a selective child-limitation policy for Muslim Rohingyas in two townships. ${ }^{30-32}$ Human rights activists have strongly criticized the government's policy, as has the United Nations. ${ }^{33}$

Rwanda and Nigeria have raised the possibility of implementing specific child-limitation policies to curb population growth, but neither country has taken formal action because of widespread opposition to such measures. In 2007, the government of Rwanda announced that it was considering a three-child policy, but the bill was never taken to parliament and the president later said that the idea of the three-child policy was part of a family planning sensitization campaign. ${ }^{34}$

Less than a month before the 2012 London Summit on Family Planning, Nigeria's president, Goodluck Jonathan, caused controversy by suggesting the country needed to implement birth control measures and possibly a threechild limit, though this appears to have been rhetoric and has not been made policy. ${ }^{35-38}$ 


\section{Mandatory or Involuntary Contraceptive Use}

Imposition of contraceptive use, like child-limitation policies, is coercive. The political will necessary to implement mandatory contraceptive use is rare and associated with authoritarian governments. As part of the enforcement of the one-child policy, China's family planning program has mandated contraceptive use, although the program is now expanding the range of methods women can use beyond the IUD after the first birth and sterilization after the second birth. ${ }^{39}$

One of the most infamous examples of this form of coercion is the forced sterilizations that occurred during the Emergency of 1975-1977 in India, when demographic concerns led the Union Health Minister to suggest to Prime Minister Indira Gandhi that "some elements of compulsion" would serve the nation's interests. ${ }^{40(p .89)}$

Over 12 months in 1976-1977, 8.3 million sterilizations (mostly vasectomies) were performed, which was more than the total number performed in the previous five years. ${ }^{41}$ Although the proportion of these sterilizations that were coerced is unknown, there is evidence that some men were physically forced by police officials to undergo sterilization. ${ }^{42}$ Vasectomy was previously acceptable to Indian men, but its prevalence has remained much lower since the Emergency period than in earlier years. The family planning program in India no longer imposes mandatory contraceptive use; however, it strongly emphasizes female sterilization, resulting in a skewed contraceptive method mix. $^{43}$

In 1995, Peruvian President Alberto Fujimori appeared to be a champion for reproductive health and a leader in Latin America, linking the rights and health of women to a larger social development agenda. However, reproductive health programming in the country became controversial when cases of coercive sterilization aimed at rural, indigenous women came to light. ${ }^{14,44-46}$ Many health care providers spoke out, confirming that they were obliged to fulfill government targets and that they could be dismissed if they did not meet targets. ${ }^{14}$ Between 200,000 and 300,000 women were sterilized as a result of a campaign conducted during Fujimori's administration. ${ }^{47-49}$ Approximately 2,000 cases of forced sterilization have been reported to the Peruvian government and the Inter-American Court of Human Rights and confirmed as violations of human rights. ${ }^{50}$

In the early days of the contraceptive implant, many providers were not willing to remove the implant before five years of use, claiming that side effects would lessen or could be treated, or that the implant was costly and therefore should not be removed early. ${ }^{51,52}$ Denying early removals, for whatever reason, violates women's right to make their own decisions about contraceptive use, and constitutes coercion in family planning. With the current expansion of implant availability and its popularity as a method, ensuring reliable access to removal by trained providers is crucial to acceptability of the method and trust in the family planning program. ${ }^{53}$

\section{Social Pressure to Adopt Family Planning}

Changing norms in countries in which the concept of family planning is new or in which there is opposition to limiting fertility is challenging. Shifting attitudes and behaviors to make it socially safe and desirable to use family planning takes time and continuous involvement of community members. Although efforts to affect fertility rates using education and informational campaigns are commonplace in family planning, the use of social pressure tactics that apply direct pressure (e.g., from leaders or authority figures) on individuals to use family planning can be considered coercive. This type of social pressure may have the effect of intimidating or manipulating people to use family planning and differs from normative social change within communities. In many countries with voluntary family planning programs, the desired number of children has decreased as the health, education and economic profile of the populace has changed. In a recent review of the proximate causes of fertility change in African countries, ${ }^{54}$ Johnson et al. found that over a 10-14-year period, the desired number of children decreased in 10 of the 13 countries included in the study.

In the early days of China's one-child policy after its inception in 1979, public pressure to comply with the policy, followed by legal sanctions and, in some cases, force, was common. ${ }^{55,56}$ Officials kept track of women's menstrual cycles and family planning use and subjected them to regular pregnancy tests; the information was often posted publicly. If one couple failed to comply with the policy, rewards were withheld from their entire work unit.

Indonesia's family planning program has been touted as a success story, but has also been accused of using heavy-handed (and by some, coercive) practices. ${ }^{57}$ The program was implemented with substantial political will that signaled to local leadership that family planning uptake was a national priority. ${ }^{8}$ In the 1970 s, the program used a community approach to promote family planning through collective action. Community leaders were expected to promote family planning and assist with changing community attitudes about family planning; it was looked upon very unfavorably, for example, if the leader's wife was not a family planning user. By one account, when family planning was being scaled up, individuals received visits from community motivators. ${ }^{58}$ If they did not adopt family planning initially, the village head or other administrators would come to the house and apply pressure on the couple to adopt family planning

As in Indonesia, leadership in Rwanda and Ethiopia has demonstrated strong commitment to improving health and lowering fertility rates through family planning services. ${ }^{59}$ In both countries, strong central leadership and community mobilization have combined to implement family planning. In Ethiopia, as a way to implement the country's Health Sector Development Programme, the "Health Development Army" has encouraged citizens to adopt a host of health behaviors, family planning among them. ${ }^{60}$ This group consists of members in the communities who exert political leader- 
ship and help to improve the community's understanding and knowledge of health issues. Although coercion has not been reported, some have raised concerns about community pressure in both Rwanda and Ethiopia. ${ }^{61,62}$

\section{Family Planning Use as a Target and Performance Indicator}

The ICPD Programme of Action was heralded as a success in part because it shifted the focus away from demographic targets. ${ }^{20}$ Numeric targets for users or acceptors of particular methods put demographic or program goals ahead of individual goals and preferences and emphasize the quantity over the quality of services provided. Targetsetting may also prompt managers, providers and community health workers to coerce individuals into accepting family planning or a particular method of contraception.

Management of the family planning program in China has been the responsibility of the central and state governments, and of managers down to local levels. Provincial and local officials are given birth quotas for their areas, with achievement evaluated in performance reviews and tied to bonuses and advancement. ${ }^{63}$ Early in India's family planning programs (1966-1967), the government implemented the Health Department-operated "Incentive-based, Target-oriented, Time-bound and Sterilization-focused" program, or the "HITTS model." Ambitious demographic targets became the responsibility of districts to achieve and led to intense pressure for managers to increase contraceptive use. ${ }^{12}$ In the 1970s, Indonesia's program, led by the Indonesian National Family Planning Board (BKKBN), was based on a voluntary approach, with a target system instituted to motivate workers to recruit new users. The target system was developed as a management tool, but was criticized by some as authoritarian and coercive. ${ }^{64}$ In Java, the program used a hierarchical system in which provincial leaders, from village heads to governors, were held accountable for family planning performance; the success of these officials in doing so was an important part of their evaluations. ${ }^{64}$ Chauls explored the allegations of coercion in Indonesia in detail, and concluded that although some coercion had likely occurred, it was very rare. ${ }^{57} \mathrm{He}$ noted that the BKKBN fundamentally understood that coercion would be "detrimental to the achievement of the program's goals." ${ }^{\text {"p. }}{ }^{28)}$ The country's shift away from targets for management purposes in the late 1990s led to the deemphasization of BKKBN's overall monitoring of local program implementation. Currently, Hayes contends that program management has suffered because BKKBN has not been able to maintain a programmatic focus without targets and has not developed new ways to reach the goal of universal access to family planning services. ${ }^{65}$

Rwanda uses performance-based contracts between the president and district mayors-adapted from a traditional concept called Imihigo-in which the local leaders take responsibility for achieving certain development targets in one year, including family planning. ${ }^{66}$ Introduced in 2006, the family planning performance indicator (the percentage of the population using modern contraceptives and family planning) is frequently highlighted as a priority for district managers. ${ }^{67,68}$

Performance-based financing for health care, a relatively new trend, has implications for family planning. Given problems that have arisen from the use of targets to increase contraceptive use in some programs in the past, there is understandable concern about the transfer of money or materials for the achievement of a performance goal or for taking a measured action in family planning programs. ${ }^{69}$ However, if implemented appropriately with emphasis on quality of care and meeting clients' reproductive intentions, this new focus may have a place in supporting expanded access to voluntary, rights-based family planning. ${ }^{70,71}$ Programs can benefit from using quantitative indicators to track progress by showing managers that services are being provided effectively or ineffectively and who has and has not received services. This information can be crucial for effective management and ensuring equity in the program, but use of such indicators is nascent and their practical application should be monitored particularly with regard to the quality of care provided.

\section{Use of Incentives and Disincentives}

The use of incentives and disincentives has been discussed for decades amid concerns that this practice might exert undue influence on family planning providers and clients. ${ }^{10,72,73}$ Over the years, some programs have introduced incentive payments for providers and clients to provide or to accept contraception or a particular method of contraception. ${ }^{74,75}$ Mason explains that although smallscale incentives can allow some individuals more choice by removing access barriers, such as transportation costs or lost wages, larger incentives to individuals are controversial. ${ }^{9}$ The critical question is whether the incentive has the effect of promoting equity in family planning decision making by leveling the field in terms of access, or has the effect of distorting the choice because the attractiveness of the incentive becomes the key motivation for accepting family planning or a specific method.

In the past, a number of countries instituted incentive schemes (e.g., Cambodia, Nepal, Philippines and Sri Lanka). Also, Bangladesh and India provide examples of family planning programs in which individuals are compensated for lost wages and travel expenses to health facilities that offer sterilization. Providers in some programs also receive payment for providing certain methods. These practices raised concerns, notably in Bangladesh, that clients were being coerced into using family planning. Extensive review of Bangladesh's family planning program found that payments to users were not influential in the decision to use family planning, and thus were not coercive. ${ }^{73,76}$ However, the per-case payments to providers and motivators (or "referral agents" and "helpers") were considered problematic and resulted in a focus on sterilization to the exclusion of other methods and the dissemination of biased information that minimized disadvantages and exaggerated the benefits of sterilization, including the compensation payment. ${ }^{73}$ 
India's program has made use of incentives to motivate providers, recruiters and users. From an early experiment to provide small sums of money to reimburse adopters for travel and lost wages, incentives became an official part of the national program in $1965 .^{12}$ Providers and motivators were given incentives for each adopter they assisted through the process (primarily sterilization) and adopters were also offered incentives. During the Emergency period in India, men were given graduated incentives for vasectomy that were based on their age and the number of children they had. ${ }^{42}$ Recently, India started offering postpartum IUDs and making a small payment to providers for each insertion. Clients have come to expect incentives from the program. ${ }^{77}$

\section{Examining Allegations of Coercion}

Although it is critical to identify and address legitimate cases of coercion, it is also important to use caution in describing programs as coercive. Unfounded allegations, often made for ideological or political reasons, negatively affect individuals and programs. East Timor, now Timor Leste, provides an example. During East Timor's independence movement in the 1980s, rumors started circulating that $57 \%$ of the women of East Timor were using the injectable, under coercion from the Indonesian government. ${ }^{78}$ In fact, only $7 \%$ of women in the country were using contraceptives at the time; of those, $57 \%$ were using the injectable. This equaled a contraceptive prevalence rate of only $4 \%$ for injectables, one of the lowest rates in Southeast Asia at the time. Further investigation did not find evidence of coercion, although the skewed method mix may indicate quality of care issues, including a lack of other options or provider bias toward the injectable. However, the rumor of Indonesian coercion persists decades later. ${ }^{79,80}$ As a result, donors have been hesitant to promote family planning in Timor Leste, leaving the country without sufficient access to contraception. This demonstrates the damage done by continued perpetuation of false allegations-creation of a situation in which it is easier for donors to walk away than to take steps to increase access to family planning services.

The case of incentives for sterilization in Bangladesh provides another example of allegations that mix ideological arguments with allegations of coercion. Compensation for sterilization-consisting of a small payment and a clean sari-started in 1965 to help defray the costs and ensure that a woman had a clean garment to wear home after surgery. For some, the payment did not cover all of the costs and for others, there was surplus, but the amount was too small to affect their decision to accept sterilization, and the sari provided after the operation was not considered a desired item of clothing. ${ }^{73,76}$ However, in 1985, allegations of coercive user payments for sterilization were leveled against the program in Bangladesh-both by the "new right" movement that wanted the United States to cut off all aid to family planning other than natural family planning, and by a group of academics and activists who opposed family planning because they considered it to be foisted on people in developing countries. ${ }^{76,81,82}$ Political appointees from the Reagan administration in the United States claimed that women could "add a new wing to their house" or "get a new party dress" from incentive payments. ${ }^{76}$ By misconstruing the real issue-that some motivators were using coercive tactics to increase uptake of family planning-steps to resolve the abuses were misdirected. After extensive investigations, the U.S. Agency for International Development (USAID) withdrew funding for all incentives because they found that incentives created a substantial vulnerability in programs. The Bangladeshi government chose not to eliminate incentives because it determined that the improved access outweighed relatively infrequent issues of coercion. ${ }^{83}$ With the elimination of payments for incentives, many of USAID's efforts to monitor family planning programming in Bangladesh also ended, removing an important element from the program. ${ }^{76}$

These examples highlight how conflict among stakeholders making various claims about coercion in programs can be detrimental to scaling up access to highquality family planning services because, for some donors, it is simpler to withdraw funding and avoid controversy. Governments can take defensive postures regarding their family planning programs that can hamper program improvement initiatives. The vast majority of family planning is voluntary-to recycle unfounded allegations of coercion in an effort to discredit whole programs does a disservice to the millions of women and men, including youth, who need and want to have the means to control their fertility.

\section{DISCUSSION \\ The Way Forward}

In some cases, coercion is egregious and needs to be addressed swiftly by identifying the specific factors that contribute to it and providing redress to victims. These factors could include political pressure, personal interests and biases, poor training, or unintended consequences of a new programming technique. Sometimes, there is a fine line between poor quality of care and coercion; for example, bad counseling or poor clinical skills may steer people toward options they do not want. However, it is important not to condemn entire programs when issues are localized and to deal with the issue at the appropriate level-within the community, by improving service quality, training and supervision, or by changing the policy that promotes coercive practices. However, it is also important to actively refute allegations that are not substantiated to preserve the reputation of the program and the trust of the community so that women are not denied the ability to plan their families because of misunderstandings or political ideologies. Due diligence in investigating coercion can lead to more appropriate responses in addressing the problem and can clarify whether the issue is coercion or one of quality of care. Family planning can be controversial and the specter of coercion has been used to discredit efforts to expand access to voluntary family planning

While it may never be possible to prevent all instances 
of coercion, we can set up programs to avoid coercion, identify instances of abuse quickly and address them appropriately. Defining coercion in terms of both violations and vulnerabilities is a start. The human rights principles and programming and the monitoring and accountability mechanisms that need to be in place to avoid coercion are clear. Many tools exist to establish family planning programs that use a human rights approach. ${ }^{20,84-88}$ A number of donors have adopted human rights-based approaches in their funding, and some governments have acknowledged human rights in their constitutions and national policies.

Monitoring and accountability mechanisms are crucial to ensuring that human rights are upheld. Policy and program safeguards must be put in place to prevent coercion and other rights abuses. Any act of coercion warrants attention; when there is widespread coercion in policy or program implementation, the remedy requires action by donors, governments and civil society to make systematic change. With an increased awareness of the vulnerabilities programs face, it may be easier to monitor family planning users' experience. Routine program monitoring should be included as part of regular program activities, but useful monitoring data may also come from a variety of places-including outside watchdogs, ad hoc reporting of cases, civil society organizations, individuals or reports in the press. A simple investigation algorithm is suggested to show a complete investigation process including redress and reporting findings (Figure 1).

Accountability systems serve programs and individuals best when they are constructive rather than adversarial. ${ }^{89}$ When donors, international governing bodies and governments focus on program improvement rather than on punitive processes that penalize programs when coercion is uncovered, they help programs respect, protect and fulfill people's right to family planning. USAID's use of the Tiahrt Amendment to ensure voluntarism is an example of a donor accountability system, although the provisions in the amendment have been noted to be necessary but not sufficient to guarantee full, free and informed choice in family planning programs. ${ }^{90}$ FP2020 as a global movement also has a role to play in ensuring voluntary, rightsbased family planning. The working groups that contribute to the implementation of FP2020 are emphasizing development of tools and indicators that can be used to identify potential problems with coercion, although there is still a need for funding the use of these tools and indicators in routine data collection. The media, including social media, can also help to spread awareness rapidly regarding human rights violations and coercive practices. In contexts such as Myanmar, the childbirth-limitation policy for Muslim Rohingyas attracted attention from media outlets such as Al Jazeera and Reuters, and the situation is being closely monitored. Furthermore, the spread of social media ensures that instances of coercion can be identified and called out more quickly and responses mobilized among stakeholders globally.
|FIGURE 1. Method for investigating coercion allegations

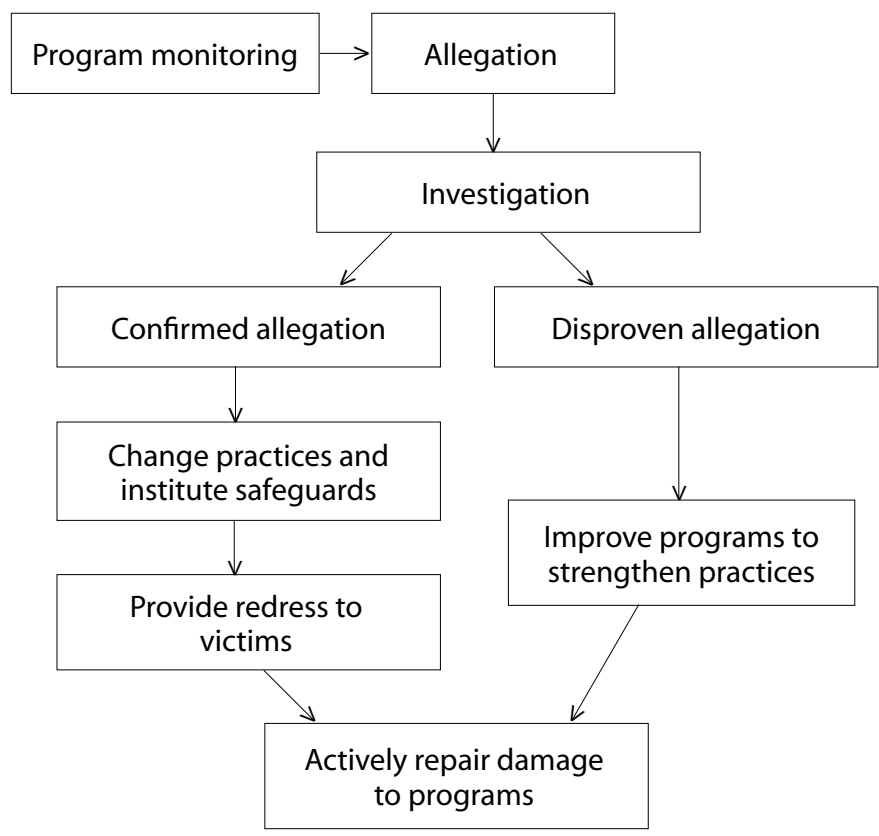

Legal mechanisms; national human rights commissions; and linking to human rights treaty bodies, such as the Committee on the Elimination of Discrimination Against Women and the Committee on Economic, Social and Cultural Rights, can be important tools for addressing rights violations. Regional human rights commissions are also important, as seen by the Kenyan National Commission on Human Rights, which received an inquiry from the Federation of Women Lawyers-Kenya and the Center for Reproductive Rights regarding the systemic problems with the reproductive health services in the country. ${ }^{91}$ This inquiry resulted in recommendations to ensure expanded availability and accessibility of information, supplies and services by increasing allocation of funds for family planning from government budgets and by addressing sociocultural barriers to access, including gender dynamics. ${ }^{92}$

Civil society groups also play a significant role in the follow-through and remediation of coercive family planning practices and human rights violations. For example, in Peru, legal organizations, the Public Ombudsman on Women's Rights, the media and the Inter-American Commission on Human Rights were involved in identifying, publicizing and prosecuting the cases of forced sterilization under the Fujimori regime. ${ }^{14,93}$ In Guatemala, efforts to hold the government accountable for the implementation of reproductive health policies led the government and the Multisectoral Monitoring Group to create the Reproductive Health Policy Implementation Board (OSAR). ${ }^{94}$ OSAR not only serves as a monitoring and accountability mechanism in the country, but also offers the opportunity for civil society groups, women's groups and researchers to contribute to the monitoring process. ${ }^{95}$ 
Conclusion

Through this review of allegations and confirmed instances of coercion, a definition of coercion in family planning has emerged. Some actions are clearly coercive and others constitute actions that have the potential to be coercive in practice. This review has also highlighted practices that raise red flags-practices that may unintentionally lead to coercion. The line between changing community norms to improve health and well-being and undue pressure on individual decision making can be blurry, and care should be taken when evaluating whether a practice or program is coercive. Although strong management systems that designate clear roles and responsibilities for family planning can have a positive effect on the efficiency and effectiveness of program implementation, management practices that include family planning targets as a performance measure can pressure managers and providers to achieve numbers without respecting and protecting the rights of individuals to full, free and informed decision making. The findings on incentives show that payments to family planning users may not be intrinsically coercive. The only definitive way to determine if incentives have a coercive effect is to assess the client experience-ask clients whether they would have made the same decision in the absence of the incentive. Finally, monitoring and accountability systems are crucial to any family planning program and must include indicators that can identify coercive practices as well as redress any confirmed instances of coercion.

It is important to remember that countries have legitimate concerns about the demographic impact on economic, social well-being and environmental issues. ${ }^{24}$ Issues of population size, growth, structure and distribution warrant attention and planning. However, demographic concerns do not override individual liberties and rights and thus cannot be used as justification for coercion. ${ }^{96,97}$ Countries concerned about demographic dynamics can address population issues with voluntary family planning programs without resorting to policies that violate human rights. ${ }^{98-100}$ The motivation to invest in family planning may come from different directions; the key is to ensure that it manifests itself in increased investment in voluntary family planning programs that respect and protect human rights.

Even one instance of coercion is unacceptable from a human rights perspective and requires rapid and thorough investigation and a prompt response from the program. Evaluating the extent to which rights violations are systemic in a program assists in identifying the appropriate corrective actions and safeguards necessary to stop the coercion and implement protective measures. Moving forward, using a human rights-based approach in the provision of voluntary family planning services can bring governments, communities, civil society and donors together to work toward the common goal of preventing coercion, increasing equitable access to family planning and ensuring that family planning programs respect, protect and fulfill human rights.

\section{REFERENCES}

1. Family Planning 2020, Family Planning 2020, 2014, <http://www. familyplanning2020.org/>, accessed Oct. 9, 2014

2. Girard F, Will the London Family Planning Initiative measure up? RH Reality Check, July 23, 2012, <http://www.rhrealitycheck.org/ article/2012/07/20/will-london-family-planning-initiative-measureup>, accessed Dec. 9, 2012

3. Khosla R, Looking for human rights at Family Planning Summit, Livewire, July 11, 2012, <http://livewire.amnesty.org/2012/07/11/ looking-for-human-rights-at-family-planning-summit/>, accessed Dec. 9, 2012.

4. Krishnan S, Highs and lows at the London Family Planning Summit, ASAP, July 12, 2012, <http://asap-asia.org/blog/highs-and-lows-at-thelondon-family-planning-summit/>, accessed Dec. 9, 2012.

5. Hodgson D and Watkins SC, Feminists and Neo-Malthusians: past and present alliances, Population and Development Review, 1997, 23(3):469-523.

6. United Nations, (UN), Final Act of the International Conference on Human Rights, New York: UN, 1968.

7. Bongaarts J and Sinding SW, A response to critics of family planning programs, International Perspectives on Sexual and Reproductive Health 2009, 35(1):39-44.

8. Warwick DP, Bitter Pills: Population Policies and Their Implementation in Eight Developing Countries, Cambridge, UK: Cambridge University Press, 1982

9. Mason KO, Do population programs violate women's human rights? Asia Pacific Issues, 1994, No. 15, pp. 1-8.

10. Bongaarts J et al., Family Planning in the 21st Century: Rationale and Design, New York: Population Council, 2012.

11. Barot S, Governmental coercion in reproductive decision making: see it both ways, Guttmacher Policy Review, 2012, 15(4):7-12.

12. Harkavy $\mathrm{O}$ and Roy $\mathrm{K}$, Emergence of the Indian national family planning program, in: Robinson WC and Ross JA, eds., The Global Family Planning Revolution: Three Decades of Population Policies and Programs, Washington, DC: World Bank, 2007, pp. 301-323.

13. Feng W, Cai Y and Gu B, Population, policy and politics: how will history judge China's one-child policy? Population and Development Review, 2013, 38(Suppl.):115-129.

14. Coe $\mathrm{AB}$, From anti-natalist to ultra-conservative: restricting reproductive choice in Peru, Reproductive Health Matters, 2004, 12(24):5669.

15. Center for Reproductive Rights (CRR), Dignity Denied: Violations of the Rights of HIV-Positive Women in Chilean Health Facilities, New York: CRR, 2010.

16. Berelson B, Beyond family planning, Studies in Family Planning, $1969,1(38): 1-16$

17. Rodriguez M et al., Voluntary Family Planning Programs That Respect, Protect and Fulfill Human Rights: A Systematic Review of Evidence, Washington, DC: Futures Group, 2013

18. Wheeler M, ICPD and its aftermath: throwing out the baby? Bulletin of the World Health Organization, 1999, 77(9):778-779.

19. Open Society Foundations (OSF), Against her will: forced and coerced sterilization of women worldwide, Fact Sheet, New York: OSF 2011.

20. United Nations Population Fund (UNFPA), Report of the International Conference on Population and Development, New York: UNFPA, 1995.

21. CRR, ICPD and Human Rights: 20 Years of Advancing Reproductive Rights Through UN Treaty Bodies and Legal Reform, New York: CRR, 2013.

22. Shalev C, Rights to sexual and reproductive health-the ICPD and the Convention on the Elimination of All Forms of Discrimination Against Women, paper presented at the International Conference on Reproductive Health, Mumbai, Mar. 15-19, 1998.

23. Erdman JN and Cook RJ, Sexual and reproductive health: repro- 
ductive rights, in: Heggenhougen HK, ed., International Encyclopedia of Public Health, Amsterdam: Elsevier, 2008, pp. 532-538.

24. United Nations High Commissioner for Refugees (UNHCR), UNHCR Note on Refugee Claims Based on Coercive Family Planning Laws or Policies, Geneva: UNHCR, 2005, <http://www.unhcr.org/refworld/ pdfid/430la9184.pdf>, accessed Mar. 27, 2013.

25. Smith AD, Namibia court rules HIV-positive women sterilised without consent, Guardian, July 30, 2012, <http://www.guardian. co.uk/global-development/2012/jul/30/namibia-hiv-womensterilised-without-consent>, accessed May 30, 2013.

26. Hoa HT et al., Child spacing and two child policy in practice in rural Vietnam: cross sectional survey, BMJ, 1996, 313(7065):1113-1116.

27. Giang LM and Huong NT, 'New bottle, but old wine': from family planning to HIV/AIDS in post-Doi Moi Vietnam, Global Public Health, 2008, 3(Suppl. 2):76-91.

28. Hanh NTT, Reproductive paradoxes in Vietnam: masculinity, contraception and abortion in Vietnam, in: Inhorn MC et al., eds., Reconceiving the Second Sex: Men, Masculinity and Reproduction, New York: Berghahn Books, 2009, pp. 160-178.

29. CRR, Women of the World: Laws and Policies Affecting Their Reproductive Lives, New York: CRR, 2005.

30. Two child limit imposed on Myanmar's Rohingya, Al Jazeera, May 25, 2013, <http://www.aljazeera.com/news/asia-pacific/ 2013/05/2013525133356670103.html>, accessed July 5, 2013.

31. Szep J and Marshall ARC, Myanmar minister backs two-child policy for Rohingya minority, Reuters, June 11, 2013, <http:// in.reuters.com/article/2013/06/11/us-myanmar-rohingyaidUSBRE95A04B20130611>, accessed June 11, 2013.

32. Associated Press, Burmese Muslims given two-child limit, Guardian, May 25, 2013, <http://www.guardian.co.uk/world/2013/may/25/ burma-muslims-two-child-limit>, accessed July 5, 2013

33. Mullen J, Suu Kyi criticizes two-child limit on Muslims in western Myanmar, CNN, May 28, 2013, <http://www.cnn.com/2013/05/28/ world/asia/myanmar-rohingya-child-limit>, accessed July 5, 2013.

34. Ndaruhuye DM, Broekhuis A and Hooimeijer P, Demand and unmet need for means of family limitation in Rwanda, International Perspectives on Sexual and Reproductive Health, 2009, 35(3):122-130.

35. Nigerian President Goodluck Jonathan urges birth control, BBC News, June 27, 2012, <http://www.bbc.co.uk/news/world-africa18610751?print=true>, accessed June 11, 2013.

36. Rosenthal E, Nigeria tested by rapid rise in population, New York Times, Apr. 14, 2012, <http://www.nytimes.com/2012/04/15/ world/africa/in-nigeria-a-preview-of-an-overcrowded-planet.html? $\mathrm{r}=2$ \&pagewanted=all\&>, accessed June 11, 2013.

37. Look A, Nigerian president's call for birth control sparks debate, Voice of America, June 28, 2012, <http://www.voanews.com/content/ nigeria-birth-control-debate/1275536.html>, accessed June 11, 2013.

38. Nigeria: row over Jonathan's birth control plan, Daily Trust, June 28, 2012, <http://allafrica.com/stories/201206280051.html>, accessed June 11, 2013.

39. Xie Z, Focusing on quality of care in the family planning programme, in: Sharing Innovative Experiences: Experiences in Addressing Population and Reproductive Health Challenges, New York: United Nations Development Programme, 2011, Vol. 19, pp. 47-71.

40. Panandiker VAP and Umashankar PK, Fertility control and politics in India, Population and Development Review, 1994, 20(Suppl.):89-104.

41. Srinivasan K, Population policies and programmes since independence: a saga of great expectations and poor performance, in: Nangia S ed., State of Natural and Human Resources of India, New Delhi: Concept Publishing, 2006, Vol. 2, pp. 266-292.

42. Brown $\mathrm{CH}$, The forced sterilization program under the Indian Emergency: results in one settlement, Human Organization, 1984 , 43(1):49-54

43. Sullivan TM et al., Skewed contraceptive method mix: why it happens, why it matters, Journal of Biosocial Science, 2006, 38(4):501-521.
44. Peru accused of sterilizing women, MSNBC, Jan. 13, 1998, <www. msnbc.com/news/136297.asp>, accessed Sept. 25, 2012.

45. Sims C, Using gifts as bait, Peru sterilizes poor women, New York Times, Feb. 15, 1998, <http://www.nytimes.com/1998/02/15/world/ using-gifts-as-bait-peru-sterilizes-poor-women.html>, accessed Sept. 28, 2012.

46. Wilson E, Reproductive Health Case Study: Peru (Draft), Washington, DC: POLICY Project/Futures Group International, 1998.

47. Thousands of forcibly sterilized Peruvian women relive the horror and demand justice, Clarin, Feb. 19, 2012, <http://www. clarin.com/america_latina/Miles-peruanas-esterilizadas-revivenjusticia_0_649135171.html>, accessed Sept. 28, 2012 (in Spanish)

48. Cordero J, Peru reopens prosecution for forced sterilizations, El Pais, Nov. 2, 2011, <http://internacional.elpais.com/ internacional/2011/11/02/actualidad/1320220460_366724.html>, accessed Sept. 28, 2012 (in Spanish)

49. Miranda JJ and Yamin AE, Reproductive health without rights in Peru, Lancet, 2004, 363(9402):68-69.

50. Romo R, Peruvian authorities reopen investigation into forced sterilizations, CNN, Nov. 17, 2011, <http://articles.cnn.com/2011-1117/americas/world americas_peru-sterilizations_1_human-rightsperuvian-authorities-peruvian-officials?_s=PM: AMERICAS>, accessed Sept. 28, 2012

51. Balasubrahmanyan V, Fix it, forget it: Norplant and human rights, Economic and Political Weekly, 1993, 28(22):1088.

52. Tolley E and Nare C, Access to Norplant removal: an issue of in formed choice, African Journal of Reproductive Health, 2001, 5(1):90-99.

53. Jacobstein $\mathrm{R}$ and Stanley $\mathrm{H}$, Contraceptive implants: providing better choice to meet growing family planning demand, Global Health Science and Practice, 2013, 1(1):11-17.

54. Johnson K, Abderrahim N and Rutstein SO, Changes in the direct and indirect determinants of fertility in Sub-Saharan Africa, DHS Analytical Studies, Calverton, MD, USA: ICF Macro, 2011, No. 23.

55. Hardee K, The success of China's one-child policy: mass desire or government control? unpublished master's thesis, Ithaca, NY, USA Cornell University, 1984

56. Kaufman J, Erli Z and Zhenming X, Quality of care in China: from pilot project to national program, paper presented at the annual meeting of the Population Association of America, Philadelphia, PA, USA, Mar. 31-Apr. 2, 2005, <http://paa2005.princeton.edu/papers/50453>, accessed July 10, 2013

57. Chauls D, Is the Indonesian family planning program coercive? paper presented at the annual conference of the National Council for International Health, Washington, DC, June 1994.

58. Warwick DP, The Indonesian family planning program: government influence and client choice, Population and Development Review, 1986, 12(3):453-490

59. Wadhams N, Progress in Rwanda's drive to slow population growth, Lancet, 2010, 376(9735):81-82.

60. Abebe B, Ethiopia: Health Development Army-decisive factor for sector enhancement, All Africa, Oct. 17, 2012, <http://allafrica.com/ stories/201210190200. html>, accessed July 16, 2013.

61. Solo J, Family Planning in Rwanda: How a Taboo Topic Became Priority Number One, Chapel Hill, NC, USA: IntraHealth International, 2008.

62. Morrison JS and Brundage S, Advancing Health in Ethiopia: With Fewer Resources, an Uncertain GHI Strategy and Vulnerabilities on the Ground, Washington, DC: Center for Strategic and International Studies, 2012

63. Burns JP and Zhou Z, Performance management in the government of the People's Republic of China: accountability and control in the implementation of public policy, OECD Journal on Budgeting, 2010 10(2):1-28

64. Lubis F, History and structure of the national family planning program, in: Niehof A and Lubis F, eds., Two Is Enough: Family Planning in Indonesia Under the New Order 1968-1998, Leiden, Netherlands: KITLV Press, 2003, pp. 31-55. 
65. Hayes AC, The status of family planning and reproductive health in Indonesia, paper presented at the UNFPA-ICOMP Regional Consultation on Family Planning in Asia and the Pacific: Addressing the Challenges, Bangkok, Dec. 8-10, 2010, <http://www.icomp.org. my/new/uploads/fpconsultation/Indonesia.pdf>, accessed Aug. 12, 2013.

66. Say L et al., Accelerating Universal Access to Reproductive Health, Geneva: World Health Organization (WHO), 2011, <http://www.who. int/reproductivehealth/publications/monitoring/Rwanda_access_ rh.pdf>, accessed July 7, 2013

67. Government of Rwanda, Local government leaders pen next year's Imihigo to address key government priorities, June 27, 2013, <http:// www.gov.rw/Local-government-leaders-pen-next-year-s-Imihigo-toaddress-key-government-priorities>, accessed Aug. 1, 2013.

68. Basinga $\mathrm{P}$ et al., Paying primary health care centers for performance in Rwanda, Policy Research Working Paper, Washington, DC: World Bank, 2010, No. 5190, <http://siteresources.worldbank. org/EXTDEVDIALOGUE/Images/537296/1238422761932/ 5968067-1269375819845/Rwanda_P4P.pdf>, accessed Aug. 9, 2013.

69. Eichler R, Can "pay for performance" increase utilization by the poor and improve the quality of health services? paper presented at the first meeting of the Working Group on Performance-Based Incentives, Washington, DC, Feb. 7, 2006.

70. Eichler R et al., Performance-Based Incentives: Ensuring Voluntarism in Family Planning Initiatives, Bethesda, MD, USA: Health Systems 20/20 project and Abt Associates, 2010.

71. Chowdhury $S$ et al., Economics and ethics of results-based financing for family planning: evidence and policy implications, Health, Nutrition and Population Discussion Paper, Washington, DC: World Bank, 2013, No. 84663

72. Berelson B, Population policy: personal notes, Population Studies, 1971, 25(2):173-182

73. Cleland J and Mauldin WP, The promotion of family planning by financial payments: the case of Bangladesh, Studies in Family Planning, 1991, 22(1):1-18.

74. National Academy of Sciences (NAS), In Search of Population Policy: Views from the Developing World, Washington, DC: NAS, 1974.

75. Palmore JA and Yap MT, Incentives, disincentives and family planning, in: Population Policies and Programmes: Current Status and Future Directions, Asian Population Studies Series, New York: UN, 1987, No. 84, pp. 113-123

76. Pillsbury B, The politics of family planning: sterilization and human rights in Bangladesh, in: Handwerker WP, ed., Births and Power: Social Change and the Politics of Reproduction, Boulder, CO, USA: Westview Press, 1990, pp. 165-196.

77. Banerjee S, Barrack-room surgery in Bihar's backwaters, The Hindu, Jan. 23, 2012, <http://www.thehindu.com/todays-paper/tp-opinion/ barrackroom-surgery-in-bihars-backwaters/article2824008.ece>, accessed Aug. 21, 2013.

78. Hull $\mathrm{TH}$, The political framework for family planning in Indonesia: three decades of development, in: Niehof A and Lubis F, eds., Two Is Enough: Family Planning in Indonesia Under the New Order 1968-1998, Leiden, Netherlands: KITLV Press, 2003, pp. 57-81.

79. Japanese International Cooperation Agency (JICA), Country Gender Profile: Timor-Leste, Final Report, Tokyo: JICA, 2011

80. Hardee K, Karen Hardee blog at London Summit on Family Planning, July 11, 2012, Washington, DC: Health Policy Project, 2012, <http:// www.healthpolicyproject.com/index.cfm?ID=FPSummitt2012>, accessed July 6, 2013

81. O'Reilly WM, The Deadly Neo-Colonialism: Report on Population Control in Bangladesh, Washington, DC: Human Life International, 1985.

82. Hartmann B and Standing H, Food, Saris and Sterilization: Population Control in Bangladesh, London: Bangladesh International
Action Group, 1985.

83. Newton G, USAID (retired), Washington, DC, personal communication, Sept. 8, 2013.

84. International Planned Parenthood Federation (IPPF), IPPF Charter on Sexual and Reproductive Rights, London: IPPF, 1996.

85. Department for International Development (DFID), Sexual and Reproductive Health and Rights: A Position Paper, London: DFID, 2004.

86. Kumar J et al., Voluntary Family Planning Programs That Respect, Protect and Fulfill Human Rights: A Systematic Review of Tools, Washington, DC: Futures Group and EngenderHealth, 2013.

87. Hardee K et al., Voluntary Family Planning Programs That Respect, Protect and Fulfill Human Rights: A Conceptual Framework, Washington, DC: Futures Group, 2013.

88. WHO, Ensuring Human Rights in the Provision of Contraceptive Information and Services: Guidance and Recommendations, Geneva: WHO, 2014

89. Cabal L, Why and when to consider human rights, paper presented at the Women Deliver conference, Kuala Lumpur, Malaysia, May 28-30, 2013.

90. EngenderHealth, Choices in Family Planning: Informed and Voluntary Decision Making, New York: EngenderHealth, 2003.

91. Cottingham J, Germain A and Hunt P, Use of human rights to meet the unmet need for family planning, Lancet, 2012, 380(9837):172-180

92. Kenya National Commission on Human Rights (KNCHR), Realising Sexual and Reproductive Health Rights in Kenya: A Myth or Reality? Nairobi, Kenya: KNCHR, 2012, <http://www.knchr.org/ Portals/0/Reports/Reproductive_health_report.pdf>, accessed Aug. 14, 2013.

93. CRR, Maria Mamerita Mestanza Chávez v. Peru (InterAmerican Commission on Human Rights), Dec. 10, 2008, <http:// reproductiverights.org/en/case/mar\%C3\%ADa-mamerita-mestanzach\%C3\%Alvez-v-peru-inter-american-commission-on-human-rights>, accessed Sept. 24, 2012.

94. Merino L, Keeping watch: accountability for FP/RH laws in Guatemala, presentation at the USAID Health Policy Initiative Task Order 1 End of Project Meeting, Washington, DC, Sept. 20, 2010.

95. Observatorio en Salud Reproductiva Guatemala, Todos y todas tienen derecho a tomar parte del gobierno de su país, <http://www. osarguatemala.org/node/126>, accessed July 30, 2013.

96. UN, International Covenant on Economic, Social and Cultural Rights, New York: UN, 1966.

97. UN, International Covenant on Civil and Political Rights, New York: UN, 1966

98. Bloom DE, Canning D and Sevilla J, The Demographic Dividend: A New Perspective on the Economic Consequences of Population Change, Santa Monica, CA, USA: RAND, 2003.

99. Gribble J and Bremner J, The Challenge of Attaining the Demographic Dividend, Washington, DC: Population Reference Bureau, 2012.

100. Sathar Z, Royan R and Bongaarts J, Capturing the Demographic Dividend in Pakistan, Islamabad, Pakistan: Population Council, 2013.

\section{Acknowledgments}

The authors thank Monica Kerrigan, Clea Finkle, Eliya Zulu and Ubaidur Rob for comments on earlier versions of the article, and Kay Willson for conducting the literature search for the article. This article is based on research funded by the Bill \& Melinda Gates Foundation. The findings and conclusions contained within are those of the authors and do not necessarily reflect positions or policies of the Bill \& Melinda Gates Foundation.

Author contact:khardee@popcouncil.org 